Original Research Article

\title{
Combating protein energy wasting in end stage kidney disease: role of exogenous proteolytic enzyme as an adjuvant to dietary protein
}

\author{
Vishal Singh*
}

Department of Medicine and Nephrology, Kanpur Cantt, Uttar Pradesh, India

Received: 14 May 2019 Accepted: 20 May 2019

*Correspondence to:

Dr. Vishal Singh,

Email: vishal23415@

gmail.com

Copyright: () the author(s), publisher and licensee Medip Academy. This is an openaccess article distributed under the terms of the Creative Commons Attribution NonCommercial License, which permits unrestricted noncommercial use, distribution, and reproduction in any medium, provided the original work is properly cited.

\begin{abstract}
Background: Despite interventions, the prevalence of protein energy wasting in patients on dialysis continues to be unacceptably high. The objective of the study is to evaluate the efficacy of exogenous proteolytic enzyme Aminace 70000 (Hemoglobin Tyrosine Unit), as an adjuvant to dietary protein in improving the nutritional status.
\end{abstract}

Methods: This is a retrospective, real world, single centre, observational study, aimed at assessing the changes in key nutritional indices, over 6 months in patients with chronic kidney disease (CKD) initiated on continuous ambulatory peritoneal dialysis (CAPD). The intervention included addition of egg protein and use of an exogenous proteolytic enzyme. Three cohorts were identified. Cohort 1 , had access to a nephrologist and CAPD counsellor; Cohort 2, in addition had access to a dietician who emphasized the need for increase in dietary protein in form of 4-6 eggs a day; and cohort 3, were in addition given an exogenous proteolytic enzyme with the major protein meal.

Results: The absolute fall in serum albumin at 6 months for the cohort 1,2 and 3 is $0.48,0.29$ and $0.09 \mathrm{gm} / \mathrm{dl}$ respectively. Not only was the fall in serum albumin significantly less with the use of exogenous proteolytic enzyme, a higher proportion of patients were able to maintain or improve their serum albumin. The fall in midarm circumference was maximum in cohort $1(2.08 \mathrm{~cm})$ and least in cohort $3(0.45 \mathrm{~cm})$. This positive trend however, did not achieve statistical significance.

Conclusions: Use of exogenous proteolytic enzyme, when combined with egg protein, improves key nutritional indices in patients of CKD on CAPD.

Keywords: Chronic kidney disease, Continuous ambulatory peritoneal dialysis, Exogenous proteolytic enzyme, Protein energy wasting

\section{INTRODUCTION}

Chronic kidney disease (CKD) represents a major public health issue and requires substantial financial and health care resources. Multiple epidemiological studies have shown that the prevalence of CKD in general population is increasing. ${ }^{1}$ Despite therapeutic advancement, the global burden of CKD and the consequent mortality continues to be high. Amongst the many factors that affect the outcome in patients with CKD, one of the key remediable variables is the nutritional status. It has been known for many years that a decrease in body protein content whether due to aging or a catabolic disease increases the risk of morbidity and mortality. ${ }^{2}$ Similar findings were also noted in patients with CKD. There exists, an inverse relationship between the serum albumin level and mortality in patients on renal replacement therapy. ${ }^{3}$ Hypoalbuminemia in patients with CKD is a culmination of various factors. These includes poor dietary intake, anorexia, dietary restriction, aging, uremic toxins, hormonal factors, presence of circulating proinflammatory markers, variability in proteolytic machinery, protein loss during dialysis, and comorbid 
medical conditions like diabetes mellitus and cardiovascular disease. Additionally, dialysis procedure in itself, stimulate protein degradation and reduces protein synthesis. Multiple metabolic and nutritional abnormalities thus coexist in patients with CKD.

Protein energy wasting (PEW) is a maladaptive metabolic state characterized by loss of body protein mass and fuel reserve. Malnutrition is often considered synonymous with PEW. The common factor binding the two entities is inadequate dietary nutrition intake; but unlike PEW, the adaptive metabolic response is preserved in malnutrition. International Society of Renal Nutrition and Metabolism (ISRNM) in the year 2007 defined PEW as a state of nutritional and metabolic derangements in patients with CKD, characterized by simultaneous loss of systematic body protein and energy stores, leading ultimately to loss of muscle and fat mass and cachexia. ${ }^{4}$ The presence of PEW has a close association with major adverse clinical outcomes including rates of hospitalization and death. ${ }^{5}$ Early detection and management of PEW using scoring tools, including subjective global assessment, PEW definition criteria and malnutrition inflammation score, forms an important part of therapeutic intervention. ${ }^{6}$ Frailty, is closely related to PEW. It is common in patients undergoing dialysis and is associated with significant morbidity and increase in all-cause mortality. ${ }^{7}$

The prevention and treatment of PEW of CKD involves an integrated approach, encompassing therapy aimed towards limiting protein and energy depletion, replenishing lost stores and evolving strategies to prevent further losses. ${ }^{8}$ The preventive strategy includes individualized continuous nutritional counselling, optimization of dialysis dose, preventing or correcting muscle wasting, and management of comorbidities. Individualization of renal diet is aimed at ensuring adherence, palatability and compatibility with cultural belief. The various therapeutic intervention advocated by ISRNM includes use of nutritional supplementation, intradialytic parenteral nutrition, exercise (resistance training) and anabolic steroids. $^{9}$ In day to day clinical practice, the surrogate nutritional markers which are readily available include serum albumin and midarm circumference. Mehrotra et. al. conducted an observational cohort study involving 130,052 dialysis patients. ${ }^{10}$ Using patients in whom the serum albumin did not change over six months as the reference group, the adjusted all-cause mortality was significantly lower among those in whom serum albumin increased by $\geq 0.3 \mathrm{~g} / \mathrm{dl}$ and significantly higher in those in whom it decreased by $\geq 0.2 \mathrm{~g} / \mathrm{dl}$. The study demonstrated that a small change in serum albumin over six months provide greater predictive value than that obtained from baseline serum albumin. Midarm circumference is an independent predictor for survival in patients on dialysis. It is a surrogate marker for lean body mass, while the triceps skin fold thickness is a surrogate for fat mass. In resource poor environment, the midarm circumference is a readily available, easily measurable surrogate for the lean body mass.
The most common nutritional intervention, employed worldwide, for prevention of CKD related PEW is dietary protein supplementation. The dietary recommendation for patients on dialysis includes consumption of 1.2 grams of protein, per kilogram body weight per day; at least $50 \%$ of which should be of high biological value. Commercially available, calorie and protein dense supplements are expensive and often inaccessible in resource poor environment. While dealing with dietary protein, an important aspect is the quality and the bioavailability or digestibility of a protein. It denotes the capacity to provide metabolically available nitrogen and amino acids to tissue and organs. Egg is a cheap, readily available, source of high biological value protein and is often used in such circumstances. The protein once ingested is broken down by the endogenous peptidases into dipeptides and tripeptides. Unbroken proteins pass unabsorbed through the gastrointestinal tract and are excreted from the body. Digestive losses and structural changes of amino acids are caused by numerous nutritional and non-nutritional factors. In patients with CKD, apart from the systemic derangement in protein metabolism, there is a derangement in the gut metabolism of proteins causing poor assimilation which in turn perpetuates the PEW. Further the effect of this unbroken protein and its interaction with the gut microbiota remains an important unanswered question.

Despite decades of research, the problem of PEW in CKD persist and the prevalence is estimated to be around 30$50 \% .{ }^{11}$ There is a thus a need to find better solution to combat PEW. Aminace 70000 Haemoglobin Unit Tyrosine (HUT) marketed by Mylin Biotech ltd, Bengaluru is a nutraceutical with unique digestive protease. It is obtained from a bacterium that helps in quick and effective degradation of proteins to small peptides. Being an exogenously administered proteolytic enzyme, it augments the protein breakdown process and improves the absorption, thus prevents unnecessary wasting of protein due to deficient digestive process.

The aim of the present study was to evaluate the efficacy of exogenous proteolytic enzyme, when given as an adjuvant to dietary egg protein. The hypothesis being, proteolytic enzyme, when administered with dietary protein supplementation, will help in better assimilation and absorption of ingested protein and thus improves the nutritional status of the patient. The serum albumin and mid arm circumference were taken as a surrogate marker for assessing the nutritional status.

\section{METHODS}

\section{Study design}

The study is a retrospective, single center, real world, open label, observational study of orally administered Aminace 70000 HUT (an exogenously administered proteolytic enzyme), with egg protein supplementation for patients in CKD stage 5 on CAPD. The data of patients freshly 
initiated on continuous ambulatory peritoneal dialysis (CAPD) from February 2011 to April 2018, from a tertiary level teaching hospital was retrospectively collated and analysed. The study was possible due to the peculiar incremental nature of the institutional CAPD program. The CAPD program from February 2011 to Jan 2016 was run by the nephrologist along with a CAPD counsellor. A dietician was included in the CAPD team in Jan 2016; who emphasized the need for increase in protein intake in form of 4 to 6 eggs per day. Aminace, was added to the program in April 2017. Approval was taken from the hospital ethical committee to collate and analyse the data. The objective of the study was to assess efficacy of Aminace, with egg protein in improving the nutritional status in patients with CKD on CAPD after 6 months of treatment.

\section{Study protocol}

The data of patients with end stage kidney disease, who were freshly initiated on CAPD during the study period, was collated and three cohorts were identified. Cohort 1 included patients who had access to only the nephrologist and the CAPD counsellor; Cohort 2 patients, had in addition, access to a dietician and were advised to consume 4-6 eggs per day; and cohort 3 were taking proteolytic enzyme supplementation along with the egg protein. The dose of Aminace, 70000 HUT was 200 milligrams, twice a day, to be taken orally, immediately after major protein meal. The clinical, anthropometric and biochemical data, at the initiation of CAPD, and at 6 months was extracted and compiled. A total of 152 patients were initiated on CAPD during the study period. The data for 13 patients was incomplete and they were excluded from the study. The key variables scrutinized included the serum albumin and the midarm circumference. For measuring the midarm circumference, the left arm was allowed to hang relaxed and the midpoint between the acromion and olecranon process was measured using commercially available measuring tape. These indices were used as a surrogate marker for the nutritional status. All the patients were followed up monthly, on outpatient basis and the dialysis and medication prescription were modified based on the prevailing clinical circumstances.

\section{Statistical analysis}

The variables analysed included serum albumin and the mid arm circumference. The data for the variables at the initiation of CAPD and at 6 months were extracted and analysed with respect to improvement, maintenance or decline in the value over time. A decline in serum albumin of $\leq 0.2 \mathrm{mg} / \mathrm{l}$, was taken as a surrogate marker for reduction in mortality. Similarly, a variability of mid arm circumference of more than $0.5 \mathrm{~cm}$ over the study period was noted and analysed. Paired t-test was used for within group comparison and post hoc Tukey's test was used for multiple comparisons between groups. A p-value $<0.05$ was considered statistically significant.

\section{RESULTS}

A total of 152 patients were initiated on CAPD during the study period. 13 patients were excluded from the study due to incomplete data. The base line demographic profile and the comorbidities of all the three cohorts are shown in Table 1. Nearly, all patients had hypertension and around $50 \%$ had type 2 diabetes mellitus.

Table 1: Baseline Demographic data of patients undergoing CAPD.

\begin{tabular}{|llllll|}
\hline Cohorts & Males (n) & Females (n) & Average age (years) & $\begin{array}{l}\text { Diabetes Mellitus } \\
\text { (Number/ percentage) }\end{array}$ & $\begin{array}{l}\text { Hypertension } \\
\text { (Number/ percentage) }\end{array}$ \\
\hline 1 & 33 & 18 & 55.68 & $21(41.1 \%)$ & $51(100 \%)$ \\
\hline 2 & 20 & 19 & 56.71 & $17(43.5 \%)$ & $37(94.8 \%)$ \\
\hline 3 & 33 & 16 & 55.30 & $25(51 \%)$ & $48(97.9 \%)$ \\
\hline
\end{tabular}

Table 2: Change in serum albumin levels at 6 months.

\begin{tabular}{|lllll|} 
Cohorts & Numbers & $\begin{array}{l}\text { Maintained or improved } \\
\text { serum albumin }\end{array}$ & $\begin{array}{l}\text { Decline of serum albumin } \\
\text { post treatment of } \mathbf{> 0 . 2} \mathbf{~ g m} / \mathbf{l}\end{array}$ & $\begin{array}{l}\text { Decline of serum albumin post } \\
\text { treatment of } \leq \mathbf{0 . 2} \mathbf{g} / \mathbf{l}\end{array}$ \\
\hline 1 & 51 & $11.76 \%(6)$ & $76.47 \%(39)$ & $11.76 \%(6)$ \\
\hline 2 & 39 & $7.69 \%(3)$ & $41.02 \%(16)$ & $51.28 \%(20)$ \\
\hline 3 & 49 & $32.65 \%(16)$ & $6.12 \%(3)$ & $61.22 \%(30)$ \\
\hline
\end{tabular}

Table 3: Serum albumin at initiation of the CAPD and at 6 months.

\begin{tabular}{|c|c|c|c|}
\hline Cohorts & $\begin{array}{l}\text { Serum albumin, baseline } \\
\text { (in } \mathrm{gm} / \mathrm{dl} \text { ) }\end{array}$ & $\begin{array}{l}\text { Serum albumin at } 6 \text { months } \\
\text { (in } \mathrm{gm} / \mathrm{dl} \text { ) }\end{array}$ & $\begin{array}{l}\text { Mean difference in serum } \\
\text { albumin }(\mathrm{gm} / \mathrm{dl})\end{array}$ \\
\hline $1(n=51)$ & $3.54 \pm 0.37$ & $3.06 \pm 0.45$ & 0.48 \\
\hline $2(n=39)$ & $3.53 \pm 0.28$ & $3.23 \pm 0.375$ & 0.29 \\
\hline $3(n=49)$ & $3.62 \pm 0.32$ & $3.53 \pm 0.37$ & 0.09 \\
\hline
\end{tabular}




\section{Serum albumin levels}

$32.65 \%$ of the patients in cohort 3 had maintained or improved serum albumin when compared to baseline (Table 2). The corresponding figures for patients in cohort 1 and 2, is $11.80 \%$ and $7.80 \%$ respectively. A decline in the serum albumin of more than $0.2 \mathrm{gm} / 1$, which has a positive correlation with mortality, was seen in $6.1 \%$ of the patients in cohort 3; the corresponding figures for patients in cohort 1 and 2 is $76.47 \%$ and $41.02 \%$ respectively. The absolute fall in serum albumin was maximum in cohort 1 $(0.48 \mathrm{gm} / \mathrm{dl})$ and least in cohort $3(0.09 \mathrm{gm} / \mathrm{dl})$ (Table 3$)$. In between cohort comparison analysis showed that the decline in serum albumin between cohort 1 and 2 was statistically insignificant. There was however a statistically significant reduction in decline of serum albumin in cohort 1 and 2 when compared to cohort 3 (Table 4).

\section{Mid arm circumference}

$36.74 \%$ of the patients in cohort 3 had maintained or improved the mid arm circumference compared to baseline; the corresponding figures for cohort 1 and 2, was $1.96 \%$ and 15.38 . A decline in the midarm circumference of more than or equal to $0.5 \mathrm{cms}$, was seen in $98 \%, 84.6 \%$ and $63.2 \%$ of patients in cohort 1,2 and 3 respectively. The absolute decline in the midarm circumference in patients of cohort 1,2 and 3 are 2.08, 0.91 and $0.45 \mathrm{~cm}$ respectively (Table 5).There was a significant reduction in decline of the midarm circumference between cohort 1 and 2 (Table 6). Though a favourable trend towards reduction in decline in midarm circumference was observed with the use of Aminase $^{\mathrm{TM}}$, it was not statistically significant.

\section{Table 4: Tukey's Post Hoc Multiple Comparison of} serum albumin at baseline and at 6 months.

\begin{tabular}{|l|l|l|}
\hline Cohorts & $\begin{array}{l}\text { Baseline value } \\
\text { (serum } \\
\text { albumin) }\end{array}$ & $\begin{array}{l}\text { At } 6 \text { months } \\
\text { (Serum } \\
\text { albumin) }\end{array}$ \\
\hline Cohort 1 Vs 2 & $\mathrm{P}<0.982$ & $\mathrm{P}<0.109$ \\
\hline Cohort 1 Vs 3 & $\mathrm{P}<0.417$ & $\mathrm{P}<0.000$ \\
\hline Cohort 2 Vs 3 & $\mathrm{P}<0.417$ & $\mathrm{P}<0.003$ \\
\hline
\end{tabular}

Table 5: Change in mid arm circumference at 6 months.

\begin{tabular}{|lllll|}
\hline Cohorts & Number & $\begin{array}{l}\text { Improved or maintained the } \\
\text { in midarm circumference }\end{array}$ & $\begin{array}{l}\text { Decline of } \geq \mathbf{0 . 5} \text { cms in } \\
\text { midarm circumference }\end{array}$ & $\begin{array}{l}\text { Overall absolute decline in } \\
\text { midarm circumference }\end{array}$ \\
\hline 1 & 51 & $1.96 \%(1)$ & $98.03 \%(50)$ & $2.08 \mathrm{cms}$ \\
\hline 2 & 39 & $15.38 \%(6)$ & $84.62 \%(33)$ & $0.91 \mathrm{cms}$ \\
\hline 3 & 49 & $36.74 \%(18)$ & $63.26 \%(31)$ & $0.45 \mathrm{cms}$ \\
\hline
\end{tabular}

Table 6: Tukey's Post Hoc multiple comparison of midarm circumference at baseline and at 6 months.

\begin{tabular}{|lll|}
\hline Cohorts & $\begin{array}{l}\text { Baseline value } \\
\text { (midarm } \\
\text { circumference) }\end{array}$ & $\begin{array}{l}\text { At 6 months } \\
\text { (midarm } \\
\text { circumference) }\end{array}$ \\
\hline Cohort-1 Vs 2 & $\mathrm{P}<0.212$ & $\mathrm{P}<0.001$ \\
\hline Cohort-1 Vs 3 & $\mathrm{P}<0.448$ & $\mathrm{P}<0.185$ \\
\hline Cohort-2 Vs 3 & $\mathrm{P}<0.01$ & $\mathrm{P}<0.090$ \\
\hline
\end{tabular}

\section{DISCUSSION}

The causes of PEW in CKD are many, and they finally culminate in disruption in energy balance with maladaptive metabolic response. PEW adversely affects the clinical outcome in patients of CKD (5). It also adversely affects the psychological effects, frailty and mobility resulting in poor quality of life (12). There is thus an urgent need to prevent and treat CKD related PEW. Over the last decade or so, our understanding of the pathophysiology of PEW has improved substantially. This has however not translated into significant improvement in clinical outcome. The basic principles to combat PEW include correction of remediable causes and increase in protein intake. Despite the best intent and aggressive therapeutic approach, PEW continues to be widespread. ${ }^{11}$ There is thus a gap in our understanding between the likely pathophysiology and implementable counter measures. Uremic milieu has multiple, intricately linked, and poorly understood effect on the substrate metabolism and gut microbiota. We feel, a more efficient metabolism, absorption and assimilation of ingested protein, may hold the key to successful therapy in PEW.

Further compounding the problem is the heterogenicity seen in Indian diet. In general, the Indian diet is protein poor and there are multiple religious and region-specific dietary restrictions. Further, financial consideration often precludes the use of proprietary energy dense, protein supplementation. Egg is an inexpensive source of high biological value protein and during the study, we noted a high degree of acceptability, including in vegetarians.

The Kidney/ Disease Outcomes Quality Initiative (K/DOQI) Clinical Practice Guidelines outline the evidence indicating that the serum albumin level is a valid and useful measure of nutritional status in dialysis patients. ${ }^{13}$ Several small and large studies indicate that 
surrogates of PEW, such as, low serum levels of albumin or inadequate protein intake, correlate with mortality. ${ }^{10,14}$ Serum albumin level and nutritional status are important survival determinants for patients receiving hemodialysis or peritoneal dialysis. ${ }^{15} \mathrm{~A}$ serum albumin level is a surrogate marker for adequacy of protein intake, dialysis adequacy, albumin loss and concurrent systemic diseases in patients with CKD. In various studies including in healthy subjects and in patients with acute or chronic illness, the serum albumin concentration is inversely related to the risk of mortality in a graded manner; the estimated increase in the odds of death ranges from $24 \%$ to $56 \%$ for each $2.5 \mathrm{~g} / \mathrm{l}$ decrease in the serum albumin concentration. ${ }^{16}$ Analysis of United States Renal Data System database showed, every $1 \mathrm{gm} / \mathrm{dl}$ fall in the serum albumin level is associated with a $39 \%$ increase in the risk of cardiovascular death. ${ }^{17}$ Serum albumin has been shown to predict all-cause mortality, and peritonitis risk in peritoneal dialysis patients. A fall in serum creatinine by $\geq 0.2 \mathrm{gm} / \mathrm{dl}$ correlates with all-cause mortality. ${ }^{10}$

The chance in the serum albumin levels over a period of time is an important prognostic tool in patient with end stage kidney disease. In the current study, a decline of serum albumin $\geq 0.2 \mathrm{gm} / \mathrm{dl}$ was seen in just $6.12 \%$ of the patients receiving exogenous proteolytic enzyme; the corresponding decline in cohort 1 and 2 was $76.47 \%$ and $41 \%$ respectively. Similarly, a higher proportion of patients $(32.65 \%)$, in cohort 3 maintained or improved the serum albumin when compared to cohort 1 and 2. The absolute fall in the serum albumin over the study period was the least for cohort 3 and maximum for cohort 1 . Inter-cohort comparison showed a significant improvement in serum albumin status in patients on exogenous proteolytic enzyme supplementation, when compared to the other cohorts. This is possibly due to enhanced metabolism, absorption and assimilation of the ingested dietary protein.

PEW is characterized by progressive loss of both fat and muscle stores of the body; between the two, it is the loss of lean body mass which is thought to be more detrimental. ${ }^{18}$ Muscle growth and maintenance involve a complex interplay between stimuli (physical activity), hormonal signalling and the supply of required substrate. The various techniques being used to assess lean body mass include dual X-ray absorptiometry, near-infrared interactance and bioelectrical impedance. The main limitation with these tools is the availability, financial consideration and lack of reproducibility. The change in the midarm circumference as a surrogate marker is a simple and inexpensive, readily available surrogate for assessment of change in the nutritional status. Higher mid arm muscle circumference are a surrogate of larger lean body mass and an independent predictor of better mental health and greater survival in maintenance haemodialysis patients. In the present study, the midarm circumference was measured at the time of initiation of the study and at 6 months. In the present study, we noted a fall in the midarm circumference in all the three cohorts. The fall was maximum in cohort $1(2.08 \mathrm{~cm})$ and least in cohort $3(0.45 \mathrm{~cm})$. The proportion of patients who maintained or improved the midarm circumference at 6 months was $1.96 \%, 15.38 \%$ and $36.74 \%$ for the cohort 1,2 and 3 respectively. It is thus apparent that exogenous proteolytic enzyme when used slows the magnitude of the fall and a higher proportion of patients were able to maintain or improve the midarm circumference over a period of 6 months. This positive trend however was not statistically significant. It is felt, that the change in midarm circumference is a slow process and a longer observation could have converted the observed positive trend to a statistically significant value.

The study highlights a novel nutritional intervention aimed towards better absorption and assimilation of dietary proteins in patients with CKD stage 5 on CAPD. Administration of Aminase 70000 HUT, a proteolytic enzyme with egg protein supplementation appears to be a promising intervention towards amelioration of CKD related PEW and clinical outcome.

Limitation of the study is , a short follow-up period and use of only few key nutritional indices as a surrogate marker for PEW are the major limitation of the study. A long term follow-up study is needed to demonstrate whether the improved nutritional status translates into a net survival benefit.

\section{CONCLUSION}

Inadequate dietary protein and energy intake is a major remediable cause of $\mathrm{PEW}$ of $\mathrm{CKD}$. In resource poor environment, hen eggs are an easily accessible and costeffective source of protein. Better and more efficient utilization of the ingested protein using exogenous proteolytic enzyme Aminace 70000 HUT, could be one of the novel methods towards combating PEW of CKD. The present study shows incremental benefit of adding proteolytic enzyme to egg protein supplementation. This is however not a substitute, but an adjuvant to other remediable factors like adequacy of dialysis, acidemia, intercurrent infection and inflammatory state, responsible for PEW.

\section{Funding: No funding sources Conflict of interest: None declared \\ Ethical approval: The study was approved by the Institutional Ethics Committee}

\section{REFERENCES}

1. Mills KT, Xu Y, Zhang W, Bundy JD, Chen CS, Kelly $\mathrm{TN}$, et al. A systematic analysis of worldwide population-based data on the global burden of chronic kidney disease in 2010. Kidney Int. 2015;88(5):950-7.

2. Griffiths RD. Muscle mass, survival, and the elderly ICU patient. Nutrition. 1996;12(6):456-8.

3. Lowrie EG, Lew NL. Death risk in hemodialysis patients: predictive value of commonly measured variables and an evaluation of death rate difference 
between facilities. Am J Kidney Dis. 1990;15(5):45882.

4. Fouque D, Kalantar-Zadeh K, Kopple J, Cano N, Chauveau P, Cuppari L, et al. A proposed nomenclature and diagnostic criteria for proteinenergy wasting in acute and chronic kidney disease. Kidney Int. 2008;73(4):391-8.

5. Kalantar-Zadeh K, Block G, McAllister CJ, Humphreys MH, Kopple JD. Appetite and inflammation, nutrition, anemia, and clinical outcome in hemodialysis patients. Am $\mathbf{J}$ Clin Nutr. 2004;80(2):299-307.

6. Riella MC. Nutritional evaluation of patients receiving dialysis for the management of protein energy wasting: What is old and what is new?. J Ren Nutr. 2013;23(3):195-98.

7. Matsuzawa R, Matsunaga A, Wang G,Yamamoto S, Kutsuna, Ishii A, et al. Relationship between lower extremity muscle strength and all-cause mortality in Japanese patients undergoing dialysis. Phys Ther. 2014;94(7):947-56.

8. Johansen KL, Painter PL, Sakkas GK, Gordon P, Doyle J, Shubert T. Effects of resistance exercise training and nandrolone decanoate on body composition and muscle function among patients who receive hemodialysis: a randomized, controlled trial. J Am Soc Nephrol. 2006;17(8):2307-14.

9. T. Alp Ikizler, Noel J. Cano, Harold Franch, Denis F, Jonathan H, Kamyar KZ, et al. Prevention and treatment of protein energy wasting in chronic kidney disease patients: A consensus statement by the International Society of Renal Nutrition and Metabolism. Kidney Int. 2013;84(6):1096-107.

10. Mehrotra R, Duong U, Jiwakanon S, Kovesdy CP, Moran J, Kopple JD, et al. Serum Albumin as a Predictor of Mortality in Peritoneal Dialysis: Comparisons with Hemodialysis. Am J Kidney Dis. 2011;58(3):418-28.

11. Fouque D, Pelletier S, Mafra D, Chauveau P. Nutrition and chronic kidney disease. Kidney Int. 2011 Aug;80(4):348-57.
12. Cohen SD, Kimmel PL. Nutritional status, psychological issues and survival in hemodialysis patients. Contrib Nephrol. 2007;155:1-17.

13. Joel D, Kopple. The National Kidney Foundation $\mathrm{K} / \mathrm{DOQI}$ clinical practice guidelines for dietary protein intake for chronic dialysis patients. Am J Kidney Dis. 2001;38(4):68-73.

14. Kalantar-Zedeh K, Kilpatrick RD, Kuwae N, McAllister CJ, Alcorn H Jr, Kopple JD, et al. Revisiting mortality predictability of serum albumin in the dialysis population: time dependency, longitudinal changes and population attributable fraction. Nephrol Dial Transplant. 2005;20(9):1880-8.

15. Vejakama $P$, Thakkinstian A, Ingsathit A, Dhanakijcharoen P, Attia J. Prognostic factors of allcause mortalities in continuous ambulatory peritoneal dialysis: a cohort study. BMC Nephrol. 2013;14:28.

16. Philip Goldwasser, Joseph Feldman. Association of serum albumin and mortality risk. J Clin Epidemiol. 1997:50(6):693-703.

17. Fung F, Sherrard DJ, Gillen DL, Wong C, Kestenbaum B, Seliger S, et al. Increased risk for cardiovascular mortality among malnourished endstage renal disease patients. Am J Kidney Dis. 2002;40(2):307-14.

18. Kakiya R, Shoji T, Tsujimoto Y, Tatsumi N, Hatsuda $\mathrm{S}$, Shinohara K, et al. Body fat mass and lean mass as predictors of survival in hemodialysis patients. Kidney Int. 2006;70(3):549-56.

Cite this article as: Singh V. Combating protein energy wasting in end stage kidney disease: role of exogenous proteolytic enzyme as an adjuvant to dietary protein. Int J Basic Clin Pharmacol 2019;8:1424-9. 